\title{
RET EXPRESSION AND ITS CORRELATION WITH CLINICOPATHOLOGIC DATA IN PAPILLARY THYROID CARCINOMA
}

\author{
Ante Punda ${ }^{1}$, Vladimir Bedeković ${ }^{2}$, Ana Barić ${ }^{1}$, Mirko Kontić ${ }^{3}, Z_{\text {aviša Čolović }}^{3}$, \\ Lucija Vanjaka Rogošić ${ }^{4}$, Hrvoje Punda ${ }^{5}$, Nenad Kunac ${ }^{6}$, Leo Grandićc ${ }^{7}$ and Valdi Pešutić Pisac ${ }^{6}$ \\ ${ }^{1}$ Department of Nuclear Medicine, Split University Hospital Centre, Split, Croatia; \\ ${ }^{2}$ Department of ENT, Sestre milosrdnice University Hospital Centre, Zagreb, Croatia; \\ ${ }^{3}$ Department of ENT, Split University Hospital Centre, Split, Croatia; \\ ${ }^{4}$ Dermatovenereology Private Surgery, Split, Croatia; \\ ${ }^{5}$ Department of Diagnostic and Interventional Radiology, Split University Hospital Centre, Split, Croatia; \\ ${ }^{6}$ Department of Pathology, Forensic Medicine and Cytology, Split University Hospital Centre, Split, Croatia; \\ ${ }^{7}$ Department of Surgery, Split University Hospital Centre, Split, Croatia
}

\begin{abstract}
SUMMARY - The purpose of this study was to analyze the possible prognostic value of RET mutation in papillary thyroid carcinoma and its incidence in the past few decades in our population, due to the increasing incidence of papillary thyroid carcinoma. The present study included $180 \mathrm{pa}-$ tients operated for papillary thyroid carcinoma. The clinical and histopathologic characteristics were analyzed. Paraffin sections of the selected histologic slides were cut again and immunohistochemically stained by the Clone 3F8 P (HIER) from Novocastra (Vision Bio Systems Europe, Newcastle upon Tyne, UK) monoclonal antibody to RET oncoprotein. Univariate analysis indicated sex ( $p=0.01)$, histologic subtype $(\mathrm{p}=0.075)$ and capsular invasion $(\mathrm{p}=0.010)$ to be statistically significant predictors of lymph node metastases, whereas age $(\mathrm{p}=0.796)$, tumor size $(\mathrm{p}=0.556)$ and intraglandular dissemination ( $\mathrm{p}=0.131)$ showed no such correlation. The presence of RET mutation $(\mathrm{p}=0.704)$ was not a statistically significant predictor of the tumor metastasizing potential. RET mutation $(\mathrm{p}=0.500)$ showed no statistically significant correlation with papillary thyroid carcinoma classifed into prognostic groups according to clinicopathologic features either. RET mutation was detected in 30\% of 180 papillary thyroid carcinomas. This is the first large study demonstrating that RET mutation incidence in papillary thyroid carcinoma in Croatian population is consistent with the classic distribution of sporadic cases, despite the increased prevalence of papillary thyroid carcinoma in the past few decades.
\end{abstract}

Key words: Mutation; Thyroid cancer, papillary; Chernobyl nuclear accident; Lymphatic metastasis; Radiation

\section{Introduction}

Rearrangement of the tyrosine kinase receptor gene (RET gene named RET/PTC) is the most common structural genetic alteration which, however,

Correspondence to: Ana Baric, $M D$, Department of Nuclear Medicine, Split University Hospital Centre, Spinčićeva 1, HR-21000 Split, Croatia

E-mail: ana.baaric@gmail.com

Received March 6, 2017, accepted October 11, 2018 shows great geographical variability ranging from 0 to $80 \%$ in different studies ${ }^{1}$. In addition, BRAF point mutation, TRK gene rearrangement and RAS mutation have been found in papillary carcinoma ${ }^{2-4}$.

RET proto-oncogene has been identified in hereditary MEN2 syndrome, and is involved in sporadic medullary and papillary thyroid carcinoma (PTC) and Hirschsprung's disease ${ }^{5}$. RET proto-oncogene is located on the long arm of chromosome 10. Genetically activated RET rearrangements are implied in the 
pathogenesis of $\mathrm{PTC}^{6}$. Variation in the prevalence of RET activation is believed to be attributable to different methods and sensitivity of the techniques used, and to environmental factors, ionizing radiation exposure in particular ${ }^{1}$.

There is no RET immunoreactivity in normal thyroid tissue ${ }^{7}$. The mean frequency of RET mutation in sporadic papillary carcinoma is $20 \%-30 \%$ in adults, rising up to $45 \%-50 \%$ in pediatric and young patients, and being highest $(50 \%-80 \%)$ in patients with a history of accidental or therapeutic radiation exposure ${ }^{8-10}$. Accordingly, it appears quite reasonable to believe that the pathomorphologically identical papillary carcinomas must have followed different routes of carcinogenesis characterized by different clinical manifestation. In the last decades, there was a significant increase in the number of PTC, so one of the possibilities was the influence of radiation like that due to Chernobyl nuclear power plant disaster ${ }^{11}$. Knowing that RET mutation has been proven to be a good marker for its influence, we decided to analyze this relationship and to evaluate if there is increament in the RET mutation incidence following the rising PTC incidence ${ }^{9}$.

\section{Patients and Methods}

\section{Patients}

The present study included 180 PTC patients operated between January 1, 1999 and December 31, 2001 at ENT Department, Split University Hospital Centre in Split. Clinical data were collected from patient medical records from Department of Nuclear Medicine files and histology findings from Department of Pathology and Cytology database. Clinical and pathologic data were analyzed and classified into two groups according to study criteria (age, sex, tumor size, histologic subtype, intraglandular dissemination, extrathyroid dissemination, and metastases): group 1 with favorable prognosis (low risk) included patients aged $<45$, female, tumor size up to $2 \mathrm{~cm}$, papillary and follicular subtype limited to the thyroid, no intraglandular dissemination, and absence of metastases; and group 2 with poor prognosis (high risk) included all those that did not meet all group 1 criteria, i.e. age $>45$, male, tumor size exceeding $2 \mathrm{~cm}$, all subtypes except for papillary and follicular ones, capsular invasion, intraglandular dissemination, and metastases to lymph nodes. At the time of the Chernobyl accident, 33\% and $66 \%$ of patients were aged $<30$ and $>30$ years, respectively.

\section{Methods}

Tissue for histologic analysis was obtained from operative material, fixed in $4 \%$ buffered formalin for $24 \mathrm{~h}$, paraffin embedded, cut into 3- to 5-m sections and stained by the standard hemalaun eosin method (HE). Paraffin sections of the selected histologic preparations were cut again and immunohistochemically stained. Antigen retrieval was performed in $10 \mathrm{mM}$ citrate buffer $(\mathrm{pH}$ 6.0) inside a microwave pressure cooker. Slides were immediately placed into a bath of tap water. Sections were washed in TBS buffer for $1 \times 5$ minutes, then placed in diluted normal serum for 10 minutes. Then the slides were incubated with primary antibody. The Clone 3F8 P (HIER) from Novocastra (Vision Bio Systems Europe, Newcastle upon Tyne, UK) monoclonal antibody to RET oncoprotein was used, at 1:40 dilution. Then the slides were washed in TBS buffer for $2 \times 5$ minutes, incubated in biotinylated secondary antibody, washed in TBS buffer for $2 \times 5$ minutes again, incubated in $\mathrm{ABC}$ reagent, washed in TBS buffer for $2 \times 5$ once more, incubated in $\mathrm{DAB}$ and washed thoroughly in running tap water. Slides were counterstained in hematoxylin, dehydrated and mounted.

The presence of RET/PTC was determined by the presence of diffuse cytoplasmic staining on the normal measuring scale (Fig. 1). The absence of staining indi-

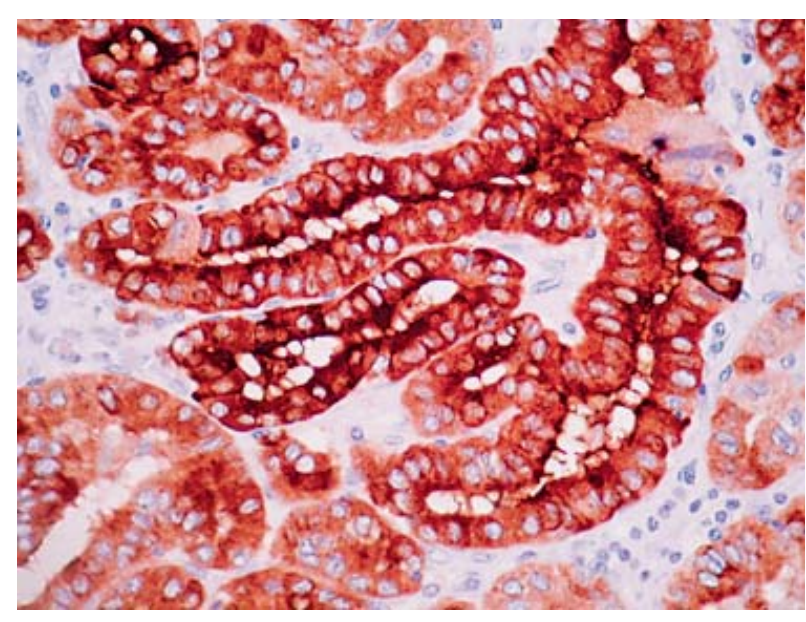

Fig. 1. Diffuse cytoplasmic staining indicates the presence of RET/PTC. 
cated absence of the study mutation. Small intestine ganglial cells were used as positive control ${ }^{12}$.

\section{Statistics}

Descriptive statistics was employed for distribution of data obtained in the patient sample, whereas Pearson's $\chi^{2}$-test, Fisher exact test and multivariate analysis of binary logistic regression were used on correlation of the results obtained. The level of statistical significance was set at $\mathrm{p}<0.05$.

\section{Results}

In the study population, patients aged $>45$ as an unfavorable prognostic factor prevailed, with a 2:1 older to younger group ratio. Sex distribution of the study population showed as many as $79.4 \%$ of female patients, yielding a 1:3.8 male to female ratio.

According to the new TNM classification, T1 tumor has a borderline size of $2 \mathrm{~cm}$, which was also adopted in the present study. Using this size criterion, carcinomas of up to $2 \mathrm{~cm}$ in size predominated ( $\mathrm{n}=130$; $72.2 \%)$. Based on the defined prognostic features of histologic subtypes and trying to facilitate analysis, papillary carcinomas were classified into two categories of favorable and unfavorable subtypes.

Papillary and follicular subtypes were classified into favorable category and accounted for as many as 146 (81.1\%) cases, whereas unfavorable category included high cellular, diffusely sclerosing and oncocytic subtypes, found in $34(18.9 \%)$ cases. Intraglandular dissemination (multifocality) was observed in $44.4 \%$ of study carcinomas. Current state-of-the-art indicates capsular invasion as a definitely poor prognostic factor. This lesion was recorded in 28 (15.6\%) and lymph node metastases in 38 (21.1\%) carcinomas. Although distant metastases from PTC are extremely rare, sporadic cases have been reported from similar large studies. In our study, however, distant metastases were not recorded at all. Analysis of immunohistochemical staining for RET mutation revealed its presence in 57 (31.7\%) patients (Table 1).

Analyzing particular characteristics of papillary carcinoma in our patients, we assessed the impact of each clinical and histologic feature on the presence of metastases. Patient age had no effect on the prevalence of metastases, as indicated by the results of $\chi^{2}$-test $(\mathrm{p}=0.796)$ and Fisher exact test $(\mathrm{p}=0.849)($ Table 2$)$.
Table 1. Frequency of RET mutation in papillary carcinoma

\begin{tabular}{|l|l|l|}
\hline RET & $\mathrm{n}$ & $\%$ \\
\hline Absent & 123 & 68.3 \\
Present & 57 & 31.7 \\
Total & 180 & 100 \\
\hline
\end{tabular}

Table 2. Lymph node metastasis in relation to clinical and histopathologic parameters

\begin{tabular}{|c|c|c|c|}
\hline \multirow[b]{2}{*}{ Variable } & \multicolumn{3}{|c|}{ Lymph node metastasis } \\
\hline & $\begin{array}{l}\text { Yes } \\
\text { n (\%) }\end{array}$ & $\begin{array}{l}\text { No } \\
\mathrm{n}(\%)\end{array}$ & $\begin{array}{l}\text { Total } \\
\mathrm{n}(\%)\end{array}$ \\
\hline $\begin{array}{l}\text { Age }(y r s)^{a} \\
\quad<45 \\
>45\end{array}$ & $\begin{array}{l}48(33.8) \\
94(66.2)\end{array}$ & $\begin{array}{l}12(31.6) \\
26(68.4)\end{array}$ & $\begin{array}{l}60(33.3) \\
120(66.7)\end{array}$ \\
\hline \begin{tabular}{|l} 
Sex $^{\mathrm{b}}$ \\
female \\
male
\end{tabular} & $\begin{array}{l}25(65.8) \\
13(34.2) \\
\end{array}$ & $\begin{array}{l}118 \\
24(\end{array}$ & $\begin{array}{l}143(79.4) \\
37(20.6)\end{array}$ \\
\hline $\begin{array}{l}\text { Tumor size } \\
\quad<2 \mathrm{~cm} \\
>2 \mathrm{~cm} \\
\end{array}$ & $\begin{array}{ll}26 & (68.4) \\
12 & (31.6) \\
\end{array}$ & $\begin{array}{l}104(73.2) \\
38(26.8)\end{array}$ & $\begin{array}{l}130(72.2) \\
50(27.8)\end{array}$ \\
\hline \begin{tabular}{|l} 
Subtype $^{\mathrm{d}}$ \\
favorable \\
unfavorable \\
\end{tabular} & $\begin{array}{l}27(71.1) \\
11(28.9)\end{array}$ & $\begin{array}{l}119(83.8) \\
23(16.2)\end{array}$ & $\begin{array}{l}146(81.1) \\
34(18.9)\end{array}$ \\
\hline \begin{tabular}{|l} 
Multifocality \\
solitary \\
dissemination \\
\end{tabular} & $\begin{array}{l}17(44.7) \\
21(55.3) \\
\end{array}$ & $\begin{array}{l}83(58.5) \\
59(41.5) \\
\end{array}$ & $\begin{array}{l}100(55.6) \\
80(44.4)\end{array}$ \\
\hline $\begin{array}{l}\text { Capsular invasion }^{\mathrm{f}} \\
\text { present } \\
\text { absent }\end{array}$ & $\begin{array}{l}11(28.9) \\
27(71.1)\end{array}$ & $\begin{array}{l}17(12.0) \\
125(88.0)\end{array}$ & $\begin{array}{l}28(15.6) \\
152(84.4)\end{array}$ \\
\hline \begin{tabular}{|l} 
RET mutation \\
present \\
absent
\end{tabular} & $\begin{array}{l}13(34.2) \\
25(65.8) \\
\end{array}$ & $\begin{array}{l}44(31.0) \\
98(69.0) \\
\end{array}$ & $\begin{array}{l}57(69.0) \\
123(77.1) \\
\end{array}$ \\
\hline
\end{tabular}

${ }^{\mathrm{a}} \chi^{2}$-test $\mathrm{p}=0.796$; Fisher exact test $\mathrm{p}=0.849 ;{ }^{\mathrm{b}} \chi^{2}$-test $\mathrm{p}=0.019$; Fisher exact test $\mathrm{p}=0.025 ;{ }^{c} \chi^{2}$-test $\mathrm{p}=0.556$; Fisher exact test $\mathrm{p}=0.547$; ${ }^{\mathrm{d}} \chi^{2}$-test $\mathrm{p}=0.075$; Fisher exact test $\mathrm{p}=0.101 ;{ }^{\mathrm{e}} \chi^{2}$-test $\mathrm{p}=0.131$; Fisher exact test $\mathrm{p}=0.145 ;{ }^{\mathrm{f}} \chi^{2}$-test $\mathrm{p}=0.010$; Fisher exact test $\mathrm{p}=0.021$; ${ }^{\mathrm{g}} \chi^{2}$-test $\mathrm{p}=0.704$; Fisher exact test $\mathrm{p}=0.699$

Metastases to lymph nodes were detected in 25 of 143 female patients and 13 of 37 male patients. Results of $\chi^{2}$-test $(\mathrm{p}=0.019)$ and Fisher exact test $(\mathrm{p}=0.025)$ revealed the prevalence of metastases to be statistically significantly higher in male patients (Table 2).

Considering the borderline tumor size of $2 \mathrm{~cm}$, the ratio of non-metastasizing to metastasizing tumors was 104:26 in the $<2 \mathrm{~cm}$ group and 38:12 in the $>2 \mathrm{~cm}$ group. Results of $\chi^{2}$-test $(\mathrm{p}=0.556)$ and Fisher exact test $(\mathrm{p}=0.547)$ showed that tumor size had no statisti- 
Table 3. Immunoreactivity to RET mutation in lowand high-risk patient groups

\begin{tabular}{|l|l|l|l|}
\hline RET & $\begin{array}{l}\text { Good } \\
\text { prognosis } \\
\text { group }\end{array}$ & $\begin{array}{l}\text { Poor } \\
\text { prognosis } \\
\text { group }\end{array}$ & Total \\
\hline Absent & 13 & 110 & 123 \\
& $10.6 \%$ & $89.4 \%$ & $100 \%$ \\
\hline \multirow{3}{*}{ Present } & $61.9 \%$ & $69.2 \%$ & $68.3 \%$ \\
\hline \multirow{3}{*}{ Total } & 8 & 49 & 57 \\
& $14.0 \%$ & $86.0 \%$ & $100 \%$ \\
& $38.1 \%$ & $30.8 \%$ & $31.7 \%$ \\
\hline & 21 & 159 & 180 \\
& $11.7 \%$ & $88.3 \%$ & $100 \%$ \\
\hline
\end{tabular}

$\chi^{2}$-test $\mathrm{p}=0.500 ;$ Fisher exact test $\mathrm{p}=0.618$

Table 4. Multivariate analysis of lymph node metastasis predictors in thyroid papillary carcinoma

\begin{tabular}{|l|l|l|}
\hline Variable & Significance & Odds ratio \\
\hline Age (yrs) & 0.384 & 0.660 \\
Sex (male/female) & 0.058 & 2.409 \\
Tumor size & 0.366 & 0.648 \\
Tumor subtype & 0.569 & 1.343 \\
Intraglandular dissemination & 0.301 & 1.556 \\
Capsular invasion & 0.083 & 2.519 \\
RET & 0.828 & 1.102 \\
\hline
\end{tabular}

cally significant impact on the occurrence of metastases (Table 2).

Division of PTCs into favorable and unfavorable subtypes revealed the presence of metastasizing potential in 27 of 146 and 11 of 34 patients, respectively. The $\chi^{2}$-test $(p=0.075)$ and Fisher exact test $(p=0.101)$ yielded a statistically significantly greater rate of metastases in the group of unfavorable subtypes (Table 2).

There was no statistically significant difference in the prevalence of metastases according to the presence of intraglandular dissemination (multifocality) $\left(\chi^{2}-\right.$ test: $\mathrm{p}=0.131$; Fisher exact test: $\mathrm{p}=0.145)$ (Table 2).

Metastases were detected in 27 of 152 cases of PTC without capsular invasion and in as many as 11 of 28 cases with capsular invasion, yielding a statistically significant between-group difference $\left(\chi^{2}\right.$-test: $p=0.010$; Fisher exact test: $p=0.021$ ). Accordingly, the prevalence of metastases was influenced by the presence of capsular invasion (Table 2).
There was no statistically significant difference in the prevalence of metastases according to the presence or absence of RET mutation as the mechanism of carcinogenesis $\left(\chi^{2}\right.$-test: $p=0.704 ;$ Fisher exact test: $\mathrm{p}=0.699$ ) (Table 2).

According to the set criteria for good and poor prognosis, 21 PTC cases met all the criteria for good prognosis, whereas 159 high-risk cases were associated with poor prognosis.

There was no statistically significant difference in the frequency of RET mutation as the mechanism of carcinogenesis between the two prognostic groups of PTC patients $\left(\chi^{2}\right.$-test: $\mathrm{p}=0.500$; Fisher exact test: $\mathrm{p}=0.618)$ (Table 3).

Univariate analysis was followed by multivariate analysis of the PTC characteristics according to the occurrence of metastases.

Binary logistic regression identified two variables that statistically significantly influenced the occurrence of metastases, i.e. male sex associated with a 2.409 risk of metastases recorded in female patients $(\mathrm{p}=0.058)$ and capsular invasion associated with a 2.519 risk of metastases found in patients free from invasion $(\mathrm{p}=0.083)$ (Table 4).

\section{Discussion}

Immunohistochemical methods of staining that enable detection of specific markers of particular cell types of normal and tumor tissue have found application in the diagnosis of thyroid carcinomas. It is known that no RET immunoreactivity is found in normal thyroid tissue 7 . In the pathogenesis of PTC, RET activation is frequently induced by radiation, mostly at younger age but also in adults ${ }^{11-13}$. RET mutation accounts for 20\%-30\% of sporadic papillary carcinomas in adults, 45\%-50\% in children and adolescents, and $50 \%-80 \%$ in patients with a history of accidental or therapeutic radiation exposure ${ }^{8-10}$. In our study population, RET mutation was detected in 57 (31.7\%) patients (Table 1), which is consistent with most studies on sporadic papillary carcinoma. These results confirmed our hypothesis that radiation exposure like the one caused by Chernobyl disaster did not contribute to the increased incidence of papillary carcinoma in the population.

Investigating the incidence of PTC during the last four decades, Jung et al. found that the proportion of 
$\mathrm{RET} / \mathrm{PTC}$ rearrangements decreased, so the increased incidence of PTC was not due to environmental or therapeutic radiation ${ }^{15}$.

Analysis of correlation between the classic parameters of PTC and their metastasizing potential revealed sex, tumor size, carcinoma variant and capsular invasion to influence the occurrence of metastases, whereas age and multifocality had no statistically significant impact on the tumor metastasizing potential (Table 2). These results are consistent with the current state-of-the-art on the role of these pathologic and clinical characteristics in papillary carcinoma ${ }^{2}$, thus our study group represented an appropriate model for additional analyses.

Analyzing the correlation between RET mutation and classic prognostic parameters in papillary carcinoma, some authors demonstrated RET mutation to be present at a higher frequency in small, slow progressing and less aggressive tumors, and conclude that it may serve as a favorable marker in these tumors ${ }^{16,17}$. This is supported by Sugg et al., who identified this mutation mostly in occult microcarcinomas ${ }^{18}$. An opposite concept has been proposed by Miki et al., based on the finding of higher RET expression in association with extrathyroid tumor invasion ${ }^{19}$.

Sassolas et al. report similar results in a population of young adults, where the presence of RET/PTC (1 and 3) was associated with histologic and clinical short-therm aggressiveness, but no such relationship was found in children and adolescents ${ }^{20}$.

In the present study, RET association with papillary carcinomas divided into prognostic categories (Table 3) according to the classic clinical and pathologic parameters was investigated. Categorization into prognostic groups by use of very strict criteria for favorable prognosis (low-risk group): age $<45$, female sex, tumor size up to $2 \mathrm{~cm}$, papillary or follicular variant confined to the thyroid, no intraglandular dissemination, and no metastases; and poor prognosis (highrisk group): those not meeting all the former group criteria, showed as many as $88.3 \%$ of study patients to belong to the high-risk group, thus highlighting the possible factors for poor prognosis. However, there was no statistically significant difference in the prevalence of RET mutation between these prognostic groups of PTC patients $\left(\chi^{2}\right.$-test: $p=0.500$; Fisher exact test: $\mathrm{p}=0.618$ ) (Table 3 ). This finding is highly comparable with the report by Shin et al. on the association of
RET expression with the clinicopathologic parameters of age, sex, tumor size, intraglandular dissemination, lymph node metastases and extrathyroid invasion ${ }^{14}$.

The researchers investigating the post-Chernobyl prevalence of papillary carcinoma in Ukraine and in young population exposed to therapeutic irradiation in childhood found a high percentage of RET mutation associated with an increased rate of lymph node metastases ${ }^{7,9,21}$. In contrast, Collins et al. found the association of young age and lymph node metastases to be more pronounced in the group of patients without a history of radiation exposure. In their study, age difference between patients with and without lymph node involvement was only recorded in the group of patients without a history of radiation exposure, thus the increased prevalence of metastases could be directly related to younger age $\mathrm{e}^{7}$. The association between RET mutation and metastasizing potential has been investigated in many studies. Jhiang et al. suggest that RET might also be associated with distant metastases in sporadic cases ${ }^{22}$, while Mayr et al. postulate it to correlate with early dissemination to lymph nodes ${ }^{23}$, which is less probable in case of distant metastases.

More recent results reveal connection of a higher rate of RAS mutation with the less aggressive nature of encapsulated follicular variant of PTC, which differs from the more aggressive infiltrative follicular variant, whereas opposite holds for the BRAF mutation pattern ${ }^{24}$.

In our study, there was no association of RET mutation with lymph node metastases, thus there was no statistically significant difference in the prevalence of metastases according to the presence or absence of RET mutation as the mechanism of carcinogenesis $\left(\chi^{2}\right.$-test: $p=0.704$; Fisher exact test: $\left.\mathrm{p}=0.699\right)$ (Table 2). The more so, RET mutation was the first parameter excluded by the stepwise method, implying its lowest possible impact (Table 4).

Considering obvious variation in the results reported from different studies including ours, it appears quite reasonable to presume that some other factors may also influence the prognostic significance of RET mutation. Also, contribution to the increased incidence of papillary carcinoma in our population is probabbly due to different factors such as better diagnostic procedures and more sophisticated medical technology. 


\section{References}

1. Santoro M, Carlomagno F, Hay ID, Hermann MA, Grieco M, et al. Ret oncogene activation in thyroid neoplasms is restricted to the papillary cancer subtype. J Clin Invest. 1992;89:1517-22. doi:10.1172/JCI115743

2. Soares P, Trovisco V, Rocha AS, Lima J, Castro P, et al. BRAF mutations and RET/PTC rearrangements are alternative events in the etiopathogenesis of PTC. Oncogene. 2003;22 (29):4578-80. doi:10.1038/sj.onc.1206706

3. Musholt TJ, Musholt PB, Khaladj N, Schulz D, Scheumann GF, et al. Prognostic significance of RET and NTRK1 rearrangements in sporadic papillary thyroid carcinoma. Surgery. 2000;128(6):984-93. doi:10.1067/msy.2000.110845

4. Şahpaz A, Önal B, Yeşilyurt A, Han Ü, Delibaşı T. BRAF(V600E) mutation, RET/PTC1 and PAX8-PPAR gamma rearrangements in follicular epithelium derived thyroid lesions - institutional experience and literature review. Balkan Med J. 2015;32(2):156-66.

doi:10.5152/balkanmedj.2015.15101

5. Lian EY, Maritan SM, Cockburn JG, Kasaian K, Crupi MJ, et al. Differential roles of RET isoforms in medullary and papillary thyroid carcinomas. Endocr Relat Cancer. 2017;24(1): 53-69. doi: 10.1530/ERC-16-0393

6. Fischer AH, Bond JA, Taysavang P, Battles OE, WynfordThomas D. Papillary thyroid carcinoma oncogene (RET/PTC) alters the nuclear envelope and chromatin structure. Am J Pathol. 1998;153:1443-50. doi:10.1016/S0002-9440(10)65731-8

7. Collins BJ, Chiapetta G, Schneider AB, Santoro M, Pentimalli F, et al. RET expression in papillary thyroid cancer from patients irradiated in childhood for benign conditions. J Clin Endocrinol Metab. 2002;87(8):3941-6. doi: $10.1210 /$ jcem. 87.8 .8748

8. Bounacer A, Wicker R, Caillou B, Cailleux AF, Sarasin A, et al. High prevalence of activating ret proto-oncogene rearrangements in thyroid tumors from patients who had received external radiation. Oncogene. 1997;15:1263-73. doi: 10.1038/sj.onc.1200206

9. Rabes HM, Demidchik EP, Sidorow JD, Lengfelder E, Beimfohr C, et al. Pattern of radiation-induced RET and NTRK1 rearrangements in 191 post-Chernobyl papillary thyroid carcinomas: biological, phenotypic, and clinical implications. Clin Cancer Res. 2000;6:1093-103.

10. Sadetzki S, Calderon-Margalit R, Modan B, Srivastava S, Tuttle RM. Ret/PTC activation in benign and malignant thyroid tumors arising in a population exposed to low-dose externalbeam irradiation in childhood. J Clin Endocrinol Metab. 2004;89(5):2281-9. doi: 10.1210/jc.2003-030481

11. LiVolsi VA, Abrosimov AA, Bogdanova T, Fadda G, Hunt JL, et al. The Chernobyl thyroid cancer experience: pathology. Clin Oncol (R Coll Radiol). 2011;23(4):261-7. doi: 10.1016/j. clon.2011.01.160
12. Cardis E, Hatch M. The Chernobyl accident - an epidemiological perspective. Clin Oncol (R Coll Radiol). 2011;23(4): 251-60. doi: 10.1016/j.clon.2011.01.510

13. Kenigsberg J, Buglova E. Health consequences. In: Smith J, Beresford N, editors. Chernobyl: Catastrophe and Consequences. New York: Springer-Verlag; 2005: p. 217-37.

14. Shin E, Chung WY, Yang WI, Cheong SP, Hong SW. RET/ PTC and CK19 expression in papillary thyroid carcinoma and its clinicopathologic correlation. J Korean Med Sci. 2005;20: 98-104. doi:10.3346/jkms.2005.20.1.98

15. Jung CK, Little MP, Lubin JH, Brenner AV, Wells SA Jr, et al. The increase in thyroid cancer incidence during the last four decades is accompanied by a high frequency of BRAF mutations and a sharp increase in RAS mutations.J Clin Endocrinol Metab. 2014;99(2):E276-85. doi: 10.1210/jc.2013-2503

16. Soares P, Fonseca E, Wynford-Thomas D, Sobrinho-Simoes M. Sporadic ret-rearranged papillary carcinoma of the thyroid: a subset of slow growing, less aggressive thyroid neoplasms? J Pathol. 1998;185:71-8. doi: 10.1002/(SICI)1096-9896 (199805)185:1<71::AID-PATH42>3.0.CO;2-S

17. Rodrigues AC, Penna G, Rodrigues E, Castro P, SobrinhoSimões $\mathrm{M}$, et al. The genetics of papillary microcarcinomas of the thyroid: diagnostic and prognostic implications. Curr Genomics. 2017;18(3):244-54. doi: 10.2174/1389202918666170105094459

18. Sugg SL, Zheng L, Rosen IB, Freeman JL, Ezzat S, et al. Ret/ PTC-1, -2 , and -3 oncogene rearrangements in human thyroid carcinomas: implications for metastatic potential? J Clin Endrocinol Metab. 1996;81:3360-5. doi: 10.1210/jcem.81.9.8784097

19. Miki H, Kitaichi M, Masuda E, Komaki K, Yamamoto Y, et al. Ret/PTC expression may be associated with local invasion of thyroid papillary carcinoma. J Surg Oncol. 1999;71:76-81.

20. Sassolas G, Hafdi-Nejjari Z, Ferraro A, Decaussin-Petrucci M, Rousset $\mathrm{B}$, et al. Oncogenic alterations in papillary thyroid cancers of young patients. Thyroid. 2012;22(1):17-26. doi:10.1089/thy.2011.0215

21. De Lellis RA, Williams ED. Tumours of the thyroid and parathyroid. In: De Lellis RA, Lloyd RV, Heitz PU, Eng C, editors. Pathology and Genetics of Tumours of Endocrine Organs. Lyon: IARC; 2004:8:49-66.

22. Jhiang SM, Caruso DR, Gilmore E, Ishizaka Y, Tahira T, et al. Detection of the PTC/retTPC oncogene in human thyroid cancers. Oncogene. 1992;7:1331-7.

23. Mayr B, Goretzki P, Ruschoff J, Dralle H. Ret/PTC-1, -2, and -3 oncogene rearrangements in human thyroid carcinomas: implications for metastatic potential? [Letter to the Editor]. J Clin Endocrinol Metab. 1997;82:1306-7. doi: 10.1210/jcem.82.4.3891-5

24. Rivera M, Ricarte-Filho J, Knauf J, Shaha A, Tuttle M, et al. Molecular genotyping of papillary thyroid carcinoma follicular variant according to its histological subtypes (encapsulated vs infiltrative) reveals distinct BRAF and RAS mutation patterns. Mod Pathol. 2010;23(9):1191-200. doi:10.1038/modpathol.2010.112 
Sažetak

\title{
UČESTALOST RET MUTACIJE U PAPILARNOM KARCINOMU ŠTITNJAČE I KORELACIJA S KLINIČKO-PATOLOŠKIM KARAKTERISTIKAMA
}

\author{
A. Punda, V. Bedeković, A. Baric, M. Kontic, Z. Čolović, L. Vanjaka Rogošic, H. Punda, \\ N. Kunac, L. Grandić i V. Pešutić Pisac
}

Cilj ovoga rada bio je ispitati moguće prognostičko značenje RET mutacije u papilarnom karcinomu štitnjače i učestalost mutacije u odnosu na porast učestalosti papilarnog karcinoma štitnjače u posljednjih nekoliko desetljeća. U istraživanje je bilo uključeno 180 bolesnika operiranih zbog papilarnog karcinoma štitnjače. Analizirane su kliničke i patohistološke osobitosti. Histološki rezovi iz parafinskih blokova odabranih uzoraka imunohistokemijski su obojani monoklonskim protutijelom na RET onkoprotein Clone 3F8 P (HIER) proizvođača Novocastra (Vision Bio Systems Europe, Newcastle upon Tyne, UK). Univarijatnom analizom utvrđena je statistički značajna povezanost spola ( $\mathrm{p}=0,01)$, histološkog podtipa $(\mathrm{p}=0,075)$ i kapsularne invazije ( $\mathrm{p}=0,010)$ kao prediktora pojave metastaza u limfne čvorove vrata, dok takva povezanost nije zabilježena za dob $(p=0,796)$, veličinu tumora $(p=0,556)$ i intraglandularnu diseminaciju tumora $(p=0,131)$. Prisutnost RET mutacije nije bila statistički značajan prediktor metastatskog potencijala tumora ( $\mathrm{p}=0,704)$. Također, RET mutacija nije bila statistički značajno povezana s prognostičkim skupinama papilarnog karcinoma koje su sastavljene na temelju kliničko-patološkh osobitosti ( $p=0,500)$. RET mutacija bila je prisutna u 30\% od 180 papilarnih karcinoma štitnjače. Ovo je prvo veće istraživanje kojim je dokazano da je RET mutacija u papilarnom karcinomu štitnjače u Hrvatskoj u skladu s učestalošću pojave spontane mutacije, iako se bilježi porast učestalosti papilarnog karcinoma štitnjače tijekom posljednjih desetljeća.

Ključne riječi: Mutacija; Tireoidni karcinom, papilarni; Černobil, nuklearna nesreća; Limfatične metastaze; Radijacija 